\title{
Nanoparticles of ZnO Doped With Mn: Structural and Morphological Characteristics
}

\author{
Maria Aparecida Ribeiro Bonifácio ${ }^{a *}$, Hélio de Lucena Lira ${ }^{a}$, \\ Laédna Souto Neiva ${ }^{b}$ Ruth H. G. A. Kiminamic, Lucianna Gama ${ }^{a}$ \\ ${ }^{a}$ Department of Materials Engineering, Federal University of Campina Grande, \\ 58429-900, Campina Grande, PB, Brazil \\ ${ }^{b}$ Academic Unit of Materials Engineering, Federal University of Cariri, \\ 63048-080, Juazeiro do Norte, CE, Brazil \\ ${ }^{c}$ Department of Materials Engineering, Federal University of São Carlos, \\ 13565-905, São Carlos, SP, Brazil
}

Received: December 14, 2015; Revised: March 17, 2017; Accepted: May 21, 2017

\begin{abstract}
In this study, the effects of dopant concentrations on the structural and morphological characteristics of $\mathrm{Zn}_{1-\mathrm{x}} \mathrm{Mn}_{\mathrm{x}} \mathrm{O}$ powders ( $\mathrm{x}=0.025,0.05,0.075$, and 0.1 mole) synthesized by the Pechini method has been investigated. The powder was characterized by X-ray diffraction (XRD), Brunauer-Emmet-Teller (BET) specific surface, energy dispersive X-ray (EDX), scanning electron microscopy (SEM) and Spectroscopy with Fourier transform (FTIR). An XRD analysis of the powder showed the formation of $\mathrm{ZnO}$ phase with a typical single phase wurtzite structure. The EDX analysis revealed Mn incorporated in the $\mathrm{ZnO}$ structure. The particle size calculated by BET ranged from 24 to $63 \mathrm{~nm}$, confirming the nanometric size of the powder particles. The SEM analysis revealed irregular shaped particle agglomerates and the presence of nanosheets. From FTIR it was confirmed the wurtzite structure in $\mathrm{ZnO}$ and $\mathrm{ZnO}$ nanoparticles doped with $\mathrm{Mn}$.
\end{abstract}

Keywords: ZnO, synthesis, Pechini method, nanopowder

\section{Introduction}

$\mathrm{ZnO}$ is a well-known optoelectronic material belonging to the wide-bandgap semiconductor family, with relatively high exciton binding energy $(\sim 60 \mathrm{meV})$. It has been extensively investigated for various applications such as varistors $^{1}$, transparent transistors ${ }^{2,3}$, sensors ${ }^{4}$, and UV light emitting devices ${ }^{5,6}$. The prediction ${ }^{7}$ that p-type $\mathrm{ZnO}$ and $\mathrm{GaN}$ may exhibit ferromagnetism characteristic above room temperature in response to doping with Mn has initiated intensive experimental work on a variety of doped diluted magnetic semiconductors (DMS $)^{8-14}$. Diluted magnetic semiconductors (DMSs), and particularly ferromagnetic oxides, are potential candidates for technological applications such as spin-transistors or the ultra-dense nonvolatile semiconductor memories ${ }^{15}$. This new field of semiconductor electronics controls and hence exploits the spin degree of freedom of the electron, in addition to or in place of its charge, for several applications. In doped $\mathrm{ZnO}$, the $\mathrm{Zn}$ ions located in the tetrahedral sites of the wurtzite structure can be substituted by magnetic transition-metal (TM) ions, thereby forming a solid solution. The presence of TM ions in these materials leads to an exchange interaction between itinerant sp-band electrons or holes and the d-electron spins localized at the magnetic ions, resulting in versatile magnetic fieldinduced functionalities ${ }^{16}$.

\footnotetext{
* e-mail: m aparecidaribeiro@yahoo.com.br
}

The polymeric precursor method, which consists in polymerizing a solution of ethylene glycol, citric acid and metal ions to form a polyester-type resin, has recently received attention because of its simplicity. This method enables the metal ions to become immobilized in a rigid polyester lattice, which greatly reduces the segregation of a particular metal during processing. Therefore, it offers a distinct advantage over most other methods, in that very pure mixed oxides can be prepared ${ }^{17}$. Furthermore, nanosized powders render the ceramic system highly attractive for the design of new functional materials, whose properties depend on particle size. Knowledge about nucleation and growth is therefore essential to control particle size ${ }^{18}$.

The aim of this work was to evaluate the effect of different concentrations of $\mathrm{Mn}^{+2}$ on the structural and morphological characteristics of $\mathrm{ZnO}$ synthesized by the polymer precursor route.

\section{Experiment}

$\mathrm{Zn}_{1-\mathrm{x}} \mathrm{Mn}_{\mathrm{x}} \mathrm{O}$ powders $(\mathrm{x}=0.025,0.05,0.075$, and 0.10$)$ were prepared by the polymeric precursor method Pechini ${ }^{19}$. Citric acid was dissolved in distilled water pre-heated at 70 ${ }^{\circ} \mathrm{C}$. The ratio of citric acid/metal cations was of $3: 1$ (in mol), according to Carreno et al. ${ }^{20}$, this relationship promotes the formation and stabilization of metallic citrate. The solution was kept under constant stirring. Next, the zinc nitrate hexahydrate $\mathrm{Zn}\left(\mathrm{NO}_{3}\right)_{2} \cdot 6 \mathrm{H}_{2} \mathrm{O}$ (from Merck) and manganese 
nitrate $\mathrm{Mn}\left(\mathrm{NO}_{3}\right)_{2} \cdot \mathrm{xH}_{2} \mathrm{O}$ (from Sigma-Aldrich) were added to the solution, in a fractional way to better homogenization. Ethylene glycol was added with a ratio of $40 / 60 \% \mathrm{w} / \mathrm{w}$ relative to the citric acid according to stoichiometric calculations. The mixture was heated to $120^{\circ} \mathrm{C}$, to form polymer resin by esterification and polyesterification reactions.

The resin was pyrolysed at temperature of $400^{\circ} \mathrm{C} / 1 \mathrm{hs}$, with heating rate of $10^{\circ} \mathrm{C} / \mathrm{min}$, to obtain a semi-carbonized material, similar to foam. Then, the material was deagglomerated, passed in a sieve with 200 mesh and calcined at $500^{\circ} \mathrm{C} / 1 \mathrm{hs}$, with heating rate of $10^{\circ} \mathrm{C} / \mathrm{min}$, to obtain the $\mathrm{ZnO}$ powder doped with manganese.

The material was characterized by powder X-ray diffraction (XRD) using a SHIMADZU XRD-6000 diffractometer operating with $\mathrm{CuK} \alpha$ radiation. The average crystallite size was calculated from the X-ray peaks, using the Scherrer equation ${ }^{21}$. The chemical compositions and microstructures of the samples were examined in an energy dispersive X-ray analyzer (EDX) coupled to a scanning electron microscope (Philips XL-30 FEG SEM). The particle morphology and size were also analyzed by scanning electron microscopy (Philips XL-30 FEG SEM). The information about the molecular geometry, intermolecular interaction and vibration present in $\mathrm{ZnO}$ nanoparticles doped with $\mathrm{Mn}$ were obtained from the analysis of infrared spectroscopy with Fourier transform (FTIR). The FTIR spectra were recorded using the spectrometer PERKIN-ELMER Spectrum 400 IR with resolution of $4 \mathrm{~cm}^{-1}$.

\section{Results and Discussion}

Figure 1 depicts the powder XRD patterns of different $\mathrm{Zn}_{1-\mathrm{x}} \mathrm{Mn}_{\mathrm{x}} \mathrm{O}(0.025<\mathrm{x} \leq 0.1)$ samples.

The XRD patterns for the powders with $\mathrm{x}>0.025$ composition indicate that the $\mathrm{ZnO}$ structure was unaffected by the substitution. The XRD patterns showed no detectable reflections due to any secondary phase. The width of the reflections increased in response to increasing Mn content, indicating decreasing particle (crystallite) size. The average particle sizes were calculated from X-ray line broadening using the Scherrer equation. Note that the average particle size decreased with increasing Mn content, which is in agreement with similar results reported in the literature ${ }^{22}$. The average particle sizes obtained in the different $\mathrm{Zn}_{1-\mathrm{x}} \mathrm{Mn}_{\mathrm{x}} \mathrm{O}$ compositions were $63,49,37$ and $24 \mathrm{~nm}$ for $\mathrm{x}=0.025,0.05,0.075$ and 0.1 , respectively. The expanded XRD patterns of the $30^{\circ}-38^{\circ}$ $2 \theta$ region shown in Figure 2 clearly indicate that the XRD reflections shifted to lower $2 \theta$ values as the concentration of $\mathrm{Mn}$ increased. This is a proof of the incorporation of $\mathrm{Mn}$ ions inside the $\mathrm{ZnO}$ crystal lattice. The ionic radius of $\mathrm{Zn}^{2+}$ is $0.60 \AA$ and of $\mathrm{Mn}^{2+}$ is $0.66 \AA$, for 4-fold coordination ${ }^{23}$. Hence, the addition of $\mathrm{Mn}$ to $\mathrm{Zn}$ causes the $\mathrm{ZnO}$ lattice to expand. A similar pattern was observed by Sasanka et al. ${ }^{24}$.

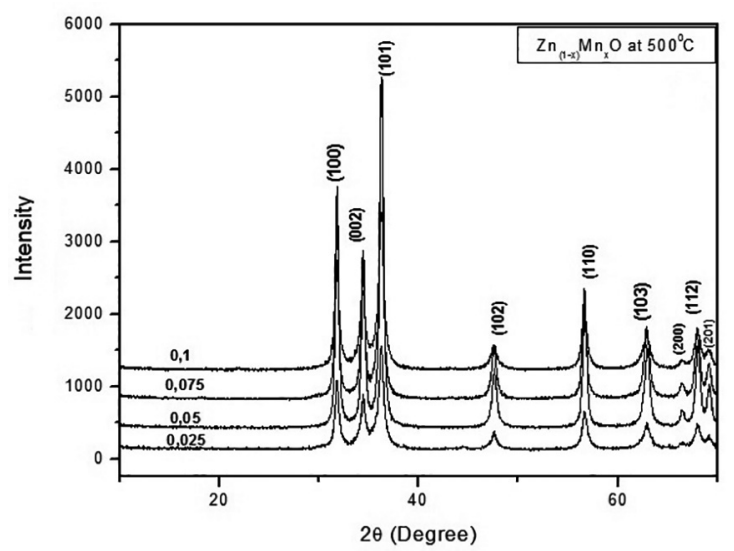

Figure 1: X-ray diffraction patterns for powders with different compositions of $\mathrm{Zn}_{1-\mathrm{x}} \mathrm{Mn}_{\mathrm{x}} \mathrm{O}(0.025<\mathrm{x} \leq 0.1)$.

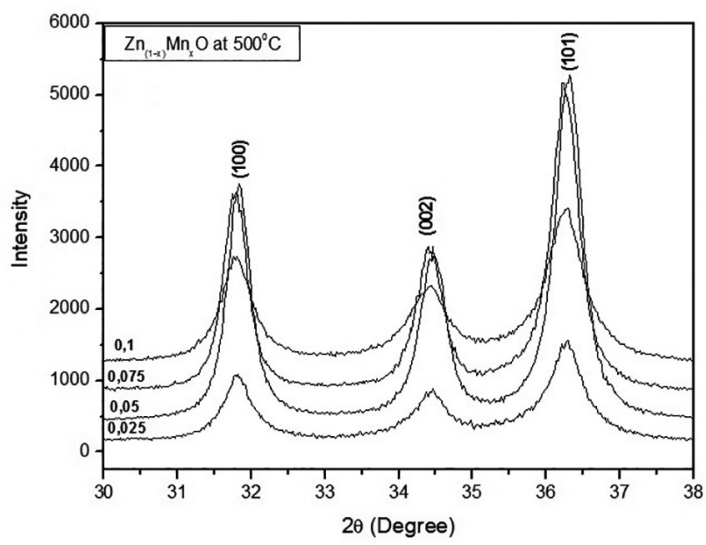

Figure 2: Comparison of the expanded XRD patterns for powders with different compositions of $\mathrm{Zn}_{1-\mathrm{x}} \mathrm{Mn}_{\mathrm{x}} \mathrm{O}(0.025<\mathrm{x} \leq 0.1)$ in the $30^{\circ}-38^{\circ} 2 \theta$ regions.

Table 1 describes the particle size $\left(\mathrm{D}_{\mathrm{BET}}\right)$, crystallite size $\left(D_{D R X}\right)$ and lattice parameter $(a=b, c)$ of the samples doped with different concentrations of Mn.

Table 1 also shows that the specific surface area increased with increasing amounts of dopant at a given temperature, while the particle size calculated by BET decreased. Table 2 lists the wt $\%$ of the elements in undoped $\mathrm{ZnO}$ and $\mathrm{Mn}$ doped Zn.

The EDX analysis revealed that the amount of Mn element in the sample increased in response to increasing $\mathrm{Mn}$ content in the solution. The incorporation of Mn can affects the optical, structural and morphological properties of $\mathrm{ZnO}$. The EDX image in Figure 3(a) shows $\mathrm{Zn}$ and $\mathrm{O}$ and (b)-(c), confirming the presence of manganese in the $\mathrm{ZnO}$ particles. Moreover, the weight percentages are very nearly equal to the nominal value of $\mathrm{Mn}$ in $\mathrm{ZnO}$. (Note: the peaks of $\mathrm{Al}$ are due to the sample holder used for depositing the samples for EDX testing. The trace Au of less than $0.1 \mathrm{wt} \%$ is due to the coating used for the SEM test). 
Table 1: Particle size, crystallite size, and lattice parameters a, b and c of samples doped with different concentrations of Mn as a function of the calcination temperature of $500^{\circ} \mathrm{C}$, for 1 hour.

\begin{tabular}{lcccc}
\hline Phase & \multicolumn{4}{c}{ Calcination temperature $500^{\circ} \mathrm{C}$} \\
& $\mathrm{D}_{\mathrm{BET}}(\mathrm{nm})$ & $\mathrm{D}_{\mathrm{DRX}}(\mathrm{nm})$ & $\mathrm{a}=\mathrm{b}(\AA)$ & 3.2491 \\
0.025 & 63 & 23 & 3.2478 & 5.2057 \\
0.05 & 49 & 20 & - & 5.2086 \\
0.075 & 37 & 14 & - & - \\
0.1 & 24 & 21 & - \\
\hline
\end{tabular}

Theoretical lattice parameter (JCPDS card 79-0205, $\mathrm{a}=\mathrm{b}=3,241 ; \mathrm{c}=5.18$ ).

Table 2: Dopant concentration (at \%) in the target material and powders

\begin{tabular}{lccc}
\hline Element & $0.025(\mathrm{wt} \%)$ & $0.05(\mathrm{wt} \%)$ & $0.075(\mathrm{wt} \%)$ \\
\hline $\mathrm{O}$ & 26.14 & 21.90 & 26.75 \\
$\mathrm{Mn}$ & - & 0.75 & 4.61 \\
$\mathrm{Zn}$ & 73.86 & 77.35 & 68.64 \\
Total & 100.00 & 100.00 & 100.00 \\
\hline
\end{tabular}

Figure 4 illustrates the nitrogen adsorption/desorption curves of the phases in samples of zinc oxide doped with different amounts of manganese.

As can be seen, the adsorption/desorption curves are of type II, with aspects of sigmoidal sorption isotherm and with hysteresis typical of mesopores. The phenomenon of hysteresis is caused by the process of capillary condensation in the structures of mesopores. The position and shapes of the hysteresis loops are closely related with the geometry of the mesopores. In Figure 4, four isotherms can be classified as type $\mathrm{H}-1$, in accordance with the IUPAC classification.
Figure 5 show SEM micrographs of $\mathrm{Zn}_{1-\mathrm{x}} \mathrm{Mn}_{\mathrm{x}} \mathrm{O}$ powder synthesized by the Pechini method and calcined at $500^{\circ} \mathrm{C}$. From Figure 5 the samples $a$ and $c$ exhibit irregular shaped particle agglomerates and the presence of nanosheets. These nanosheets are interconnected and have approximately uniform size. Sample $b$, on the other hand, shows high porosity and a high degree of agglomeration.

Figure 6 shows the FTIR spectra for the composition $\mathrm{Zn}_{1-\mathrm{x}} \mathrm{Mn}_{\mathrm{x}} \mathrm{O}$ with $(\mathrm{x}=0.025,0.05$ and $0.075,0.10)$, respectively. The strong band is observed centered at $450 \mathrm{~cm}^{-1}$ for all the samples and is assigned to the asymmetric stretching vibration of the group $\mathrm{O}-\mathrm{Zn}-\mathrm{O}$ in the octahedral coordination, while the peak at approximately $620 \mathrm{~cm}^{-1}$ is assigned to the group stretch of Mn-O. These bands confirm the wurtzite structure in $\mathrm{ZnO}$ and $\mathrm{ZnO}$ nanoparticles doped with $\mathrm{Mn}$. The absorption band in the range between $3350-3650 \mathrm{~cm}^{-1}$ is assigned to the $-\mathrm{OH}$ groups of $\mathrm{H} 2 \mathrm{O}$, indicating the existence of water absorbed on the surface of the nanoparticles of $\mathrm{ZnO}$. The two absorption peaks observed at 1400 and $1600 \mathrm{~cm}^{-1}$ correspond

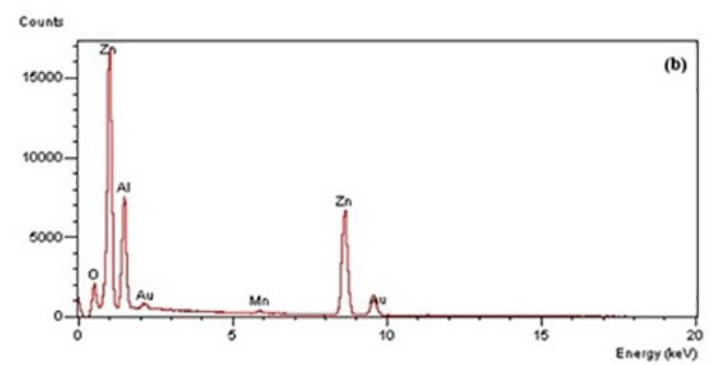

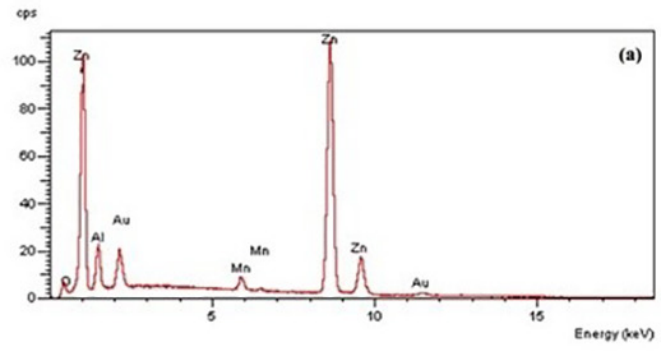

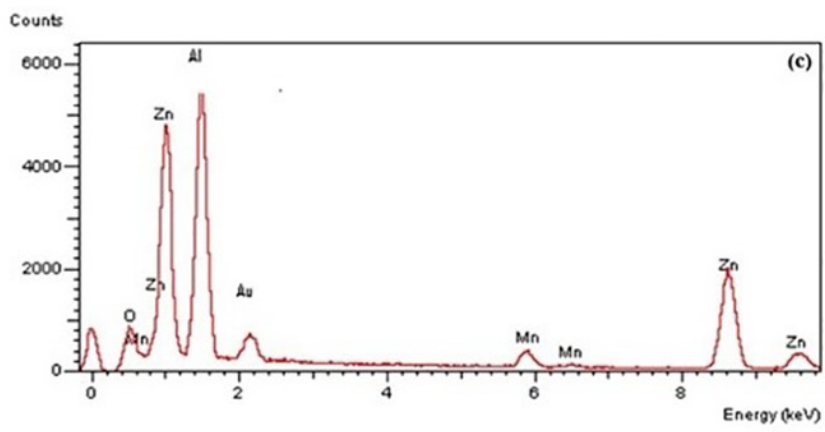

Figure 3: EDX image of the samples $(\mathrm{a}-\mathrm{c})$ calcined at $500^{\circ} \mathrm{C}$ for $1 \mathrm{~h}$ on air. 

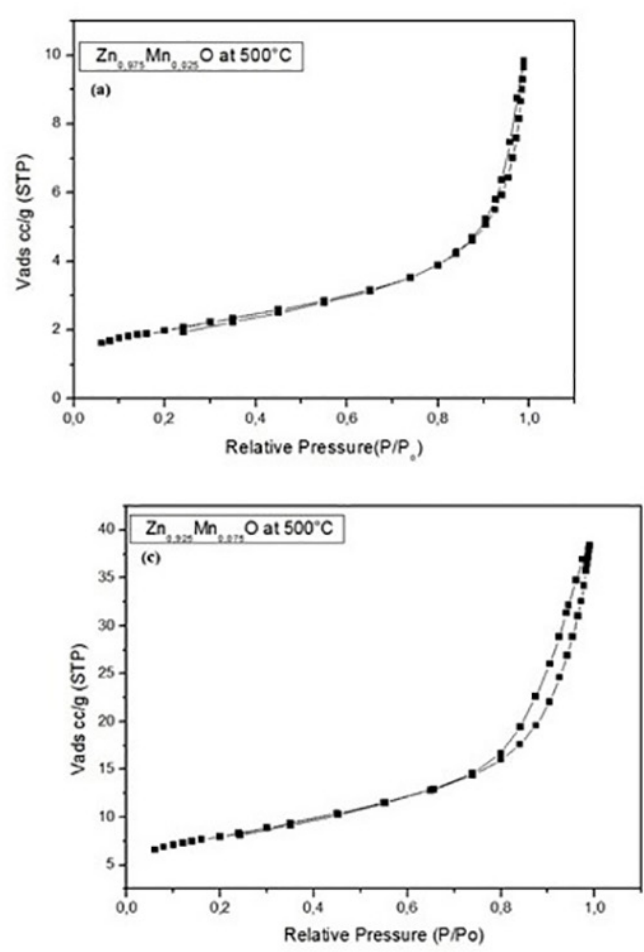
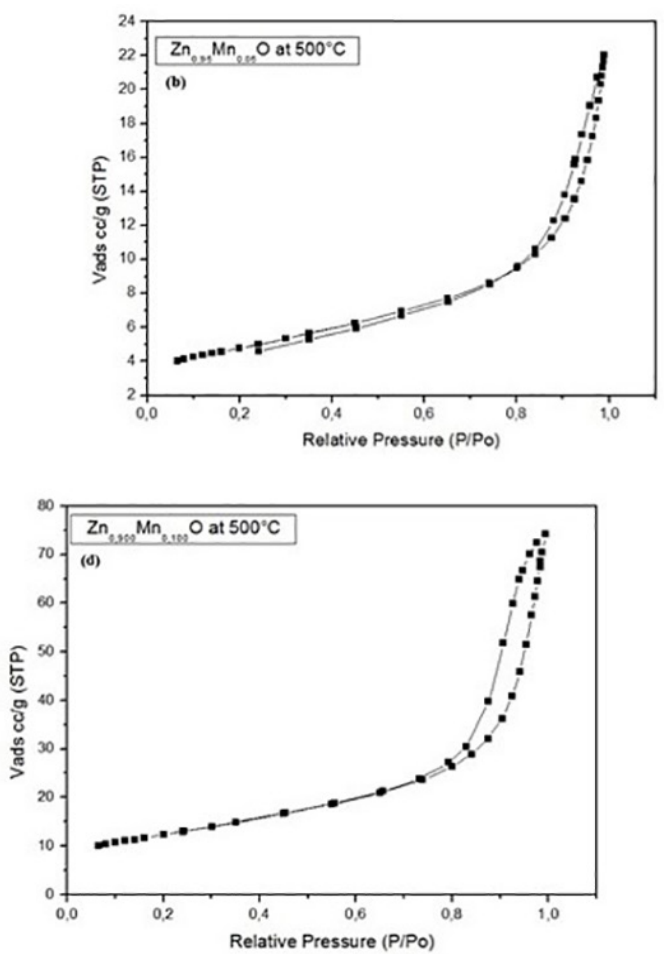

Figure 4: Nitrogen adsorption/desorption isotherms of zinc oxide powder doped with manganese and calcined at $500^{\circ} \mathrm{C}:\left(\right.$ a) $\mathrm{Zn}_{0.975} \mathrm{Mn}_{0.025} \mathrm{O}$; (b) $\mathrm{Zn}_{0.950} \mathrm{Mn}_{0.050} \mathrm{O}$; (c) $\mathrm{Zn}_{0.925} \mathrm{Mn}_{0.075} \mathrm{O}$, and (d) $\mathrm{Zn}_{0.900} \mathrm{Mn}_{0.100} \mathrm{O}$.
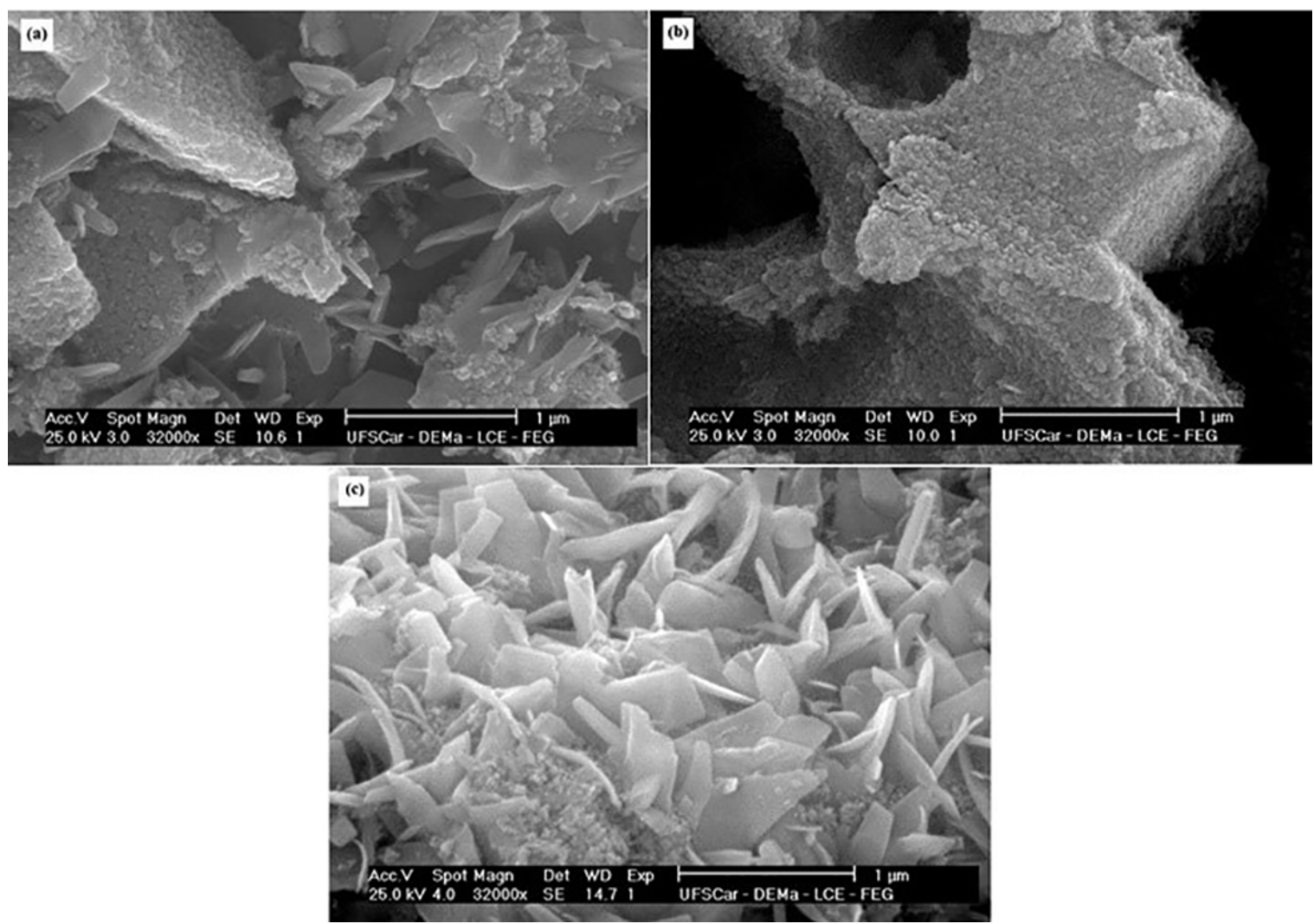

Figure 5: SEM micrographs of the morphology of $\mathrm{Zn}_{1-\mathrm{x}} \mathrm{Mn}_{\mathrm{x}} \mathrm{O}$ prepared by the Pechini method and calcined at $500^{\circ} \mathrm{C}:(\mathrm{a}) \mathrm{Zn}_{0.975} \mathrm{Mn}_{0.025} \mathrm{O}$; (b) $\mathrm{Zn}_{0.95} \mathrm{Mn}_{0.05} \mathrm{O}$, and (c) $\mathrm{Zn}_{0.925} \mathrm{Mn}_{0.075} \mathrm{O}$. Magnification $\mathrm{x} 320000$. 

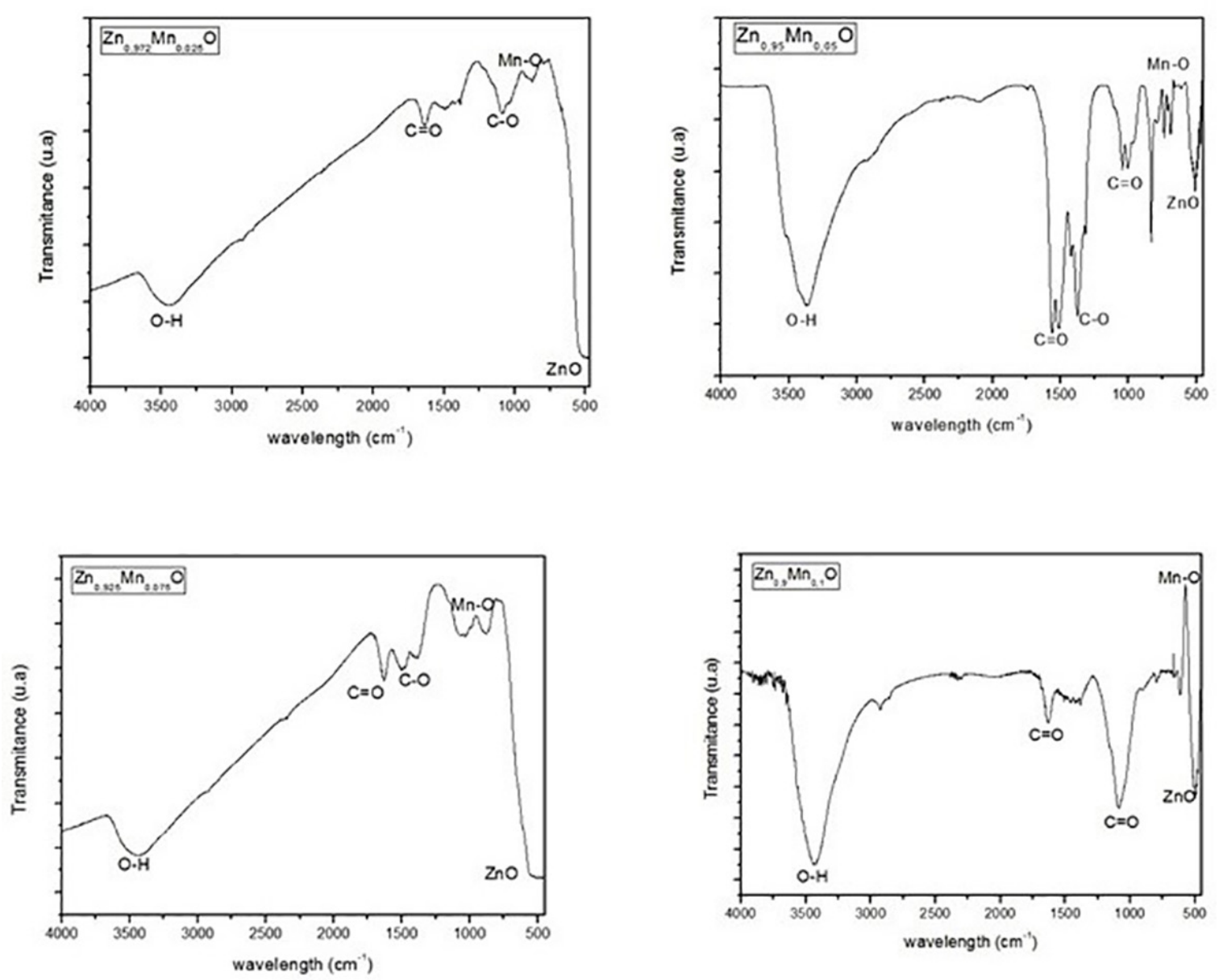

Figure 6: FTIR spectra for the composition $\mathrm{Zn}_{1-\mathrm{x}} \mathrm{Mn}_{\mathrm{x}} \mathrm{O}(\mathrm{x}=0.025,0.05,0.075$ and 0.1$)$.

to the symmetric and asymmetric $\mathrm{C}=\mathrm{O}$ bond stretching. The deformation bands of $\mathrm{C}=\mathrm{O}$ can also be observed at $980 \mathrm{~cm}^{-1}$.

\section{Conclusions}

Nanocrystalline $\mathrm{Zn}_{1-\mathrm{x}} \mathrm{Mn}_{\mathrm{x}} \mathrm{O}$ powders with $\mathrm{x}=0.025$, $0.05,0.075$, and 0.1 mole hve been synthesized. The X-ray diffraction patterns of the samples showed the formation of $\mathrm{ZnO}$ phase as main phase. The crystallite size of the samples calcined at $500^{\circ} \mathrm{C}$ changed from 14 to $23 \mathrm{~nm}$, confirming the nanometric size of the powder particles. The lattice parameters increased in response to increasing dopant content, due to a structural defect. The EDX analysis confirmed the presence of manganese in the $\mathrm{ZnO}$ lattice. An analysis of the sorption curves indicated that the phases calcined at $500^{\circ} \mathrm{C}$ contained mesopores and $\mathrm{H}-1$ type hysteresis. The powder morphology revealed the formation of irregular shaped soft agglomerates and the presence of nanosheets. These findings confirmed the effectiveness of the Pechini method for the production of ceramic powders with nanoscale features. From FTIR it was confirmed the wurtzite structure in $\mathrm{ZnO}$ and $\mathrm{ZnO}$ nanoparticles doped with Mn.

\section{Acknowledgements}

The authors gratefully acknowledge the financial support of the Brazilian research funding agencies $\mathrm{CNPq}$ (National Council for Scientific and Technological Development) and CAPES-PROCAD (National Program of Academic Cooperation [PROCAD] of the Federal Agency for the Support and Improvement of Higher Education [CAPES]).

\section{References}

1. Sato Y, Yodogawa M, Yamamoto T, Shibata N, Ikuhara Y. Dopantsegregation-controlled $\mathrm{ZnO}$ single-grain-boundary varistors. Applied Physics Letters. 2005;86(15):152112.

2. Fortunato EMC, Barquinha PMC, Pimentel ACMBG, Gonçalves AMF, Marques AJS, Martins RFP, et al. Wide-bandgap highmobility $\mathrm{ZnO}$ thin-film transistors produced at room temperature. Applied Physics Letters. 2004;85(13):2541. 
3. Ryu YR, Lee TS, Lubguban JA, White HW, Park YS, Youn CJ. $\mathrm{ZnO}$ devices: Photodiodes and $p$-type field-effect transistors. Applied Physics Letters. 2005;87(15):153504.

4. Batista PD, Mulato M. ZnO extended-gate field-effect transistors as $p \mathrm{H}$ sensors. Applied Physics Letters. 2005;87(14):143508.

5. Ohta H, Hirano M, Nakahara K, Maruta H, Tanabe T, Kamiya $\mathrm{M}$, et al. Fabrication and photoresponse of a pn -heterojunction diode composed of transparent oxide semiconductors, $\mathrm{p}-\mathrm{NiO}$ and n-ZnO. Applied Physics Letters. 2003;83(5):1029.

6. Dole BN, Mote VD, Huse VR, Purushotham Y, Lande MK, Jadhav $\mathrm{KM}$, et al. Structural studies of $\mathrm{Mn}$ doped $\mathrm{ZnO}$ nanoparticles. Current Applied Physics. 2011;11(3):762-766.

7. Dietl T, Ohno H, Matsukura F, Cibert J, Ferrand D. Zener Model Description of Ferromagnetism in Zinc-Blende Magnetic Semiconductors. Science. 2000;287(5455):1019-1022.

8. Hong J, Wu RQ. Magnetic ordering and x-ray magnetic circular dichroism of Co doped ZnO. Journal of Applied Physics. 2005;97(6):063911.

9. Kane MH, K. Shalini K, Summers CJ, Varatharajan R, Nause $\mathrm{J}$, Vestal CR, et al. Magnetic properties of bulk $\mathrm{Zn}_{1-\mathrm{x}} \mathrm{Mn}_{\mathrm{x}} \mathrm{O}$ and $\mathrm{Zn}_{1-\mathrm{x}} \mathrm{Co}_{\mathrm{x}} \mathrm{O}$ single crystals. Journal of Applied Physics. 2005;97(2):023906.

10. Sharma P, Gupta A, Rao KV, Owens FJ, Sharma R, Ahuja $\mathrm{R}$, et al. Ferromagnetism above room temperature in bulk and transparent thin films of Mn-doped. Nature Materials. 2003;2(10):673-677.

11. Hasuike N, Fukumura H, Harima H, Kisoda K, Hashimoto M, Zhou YK, et al. Optical studies on GaN-based spintronics materials. Journal of Physics: Condensed Matter. 2004;16(48):S5811.

12. Pakhomov AB, Roberts BK, Tuan A, Shutthanandan V, McCready D, Thevuthasan S, et al. Studies of two- and three-dimensional ZnO:Co structures through different synthetic routes. Journal of Applied Physics. 2004;95(11):7393.

13. Heo YW, Ivill MP, Ip K, Norton DP, Pearton SJ, Kelly JG, et al. Effects of high-dose $\mathrm{Mn}$ implantation into $\mathrm{ZnO}$ grown on sapphire. Applied Physics Letters. 2004;84(13):2292.
14. Jung SW, An SJ, Yi GC, Jung CU, Lee SI, Cho S. Ferromagnetic properties of $\mathrm{Zn}_{1-\mathrm{x}} \mathrm{Mn}_{\mathrm{x}} \mathrm{O}$ epitaxial thin films. Applied Physics Letters. 2002;80(4):4561.

15. Alaria J, Turek P, Bernard M, Bouloudenine M, Berbadj A, Brihi $\mathrm{N}$, et al. No ferromagnetism in $\mathrm{Mn}$ doped $\mathrm{ZnO}$ semiconductors. Chemical Physics Letters. 2005;415(4-6):337-341.

16. Ghosh CK, Das S, Chattopadhyay KK. Enhancement of thermopower of $\mathrm{Mn}$ doped $\mathrm{ZnO}$ thin film. Physica B: Condensed Matter. 2007;399(1):38-46.

17. Kakihana M. Invited review "sol-gel" preparation of high temperature superconducting oxides. Journal of Sol-Gel Science and Technology. 1996;6(1):7-55.

18. Gama L, Ribeiro MA, Barros BS, Kiminami RHA, Weber IT, Costa ACFM. Synthesis and characterization of the $\mathrm{NiAl}_{2} \mathrm{O}_{4}$, $\mathrm{CoAl}_{2} \mathrm{O}_{4}$ and $\mathrm{ZnAl}_{2} \mathrm{O}_{4}$ spinels by the polymeric precursors method. Journal of Alloys and Compounds. 2009;483(1-2):453-455.

19. Pechini MP, inventor. Method of preparing lead and alkaline earth titanates and niobates and coating method using the same to form a capacitor. United States patent 3.330.697. $1967 \mathrm{Jul} 11$.

20. Carreño NLV, Leite ER, Santos LPS, Lisboa-Filho PN, Longo E, Araújo GCL, et al. Síntese, Caracterização e Estudo das Propriedades Catalíticas e Magnéticas de Nanopartículas de Ni Dispersas em Matriz Mesoporosa de $\mathrm{SiO}_{2}$. Química Nova. 2002;25(6A):935-942.

21. Klung H, Alexander L. X-ray Diffraction Procedures. Hoboken: Wiley; 1954.

22. Luo J, Liang JK, Liu QL, Liu FS, Zhang Y, Sun BJ, et al. Structure and magnetic properties of $\mathrm{Mn}$-doped $\mathrm{ZnO}$ nanoparticles. Journal of Applied Physics. 2005;97(8):086106.

23. Shannon RD. Revised effective ionic radii and systematic studies of interatomic distances in halides and chalcogenides. Acta Crystallographica Section A. 1976;32(Pt 5):751-767.

24. Deka S, Joy PA. Synthesis and magnetic properties of Mn doped ZnO nanowires. Solid State Communications. 2007;142(4):190-194. 